\title{
Segmentasi Pasar Dalam Komunikasi Pemasaran Islam
}

\author{
Novan Hariyansah \\ Universitas Islam Negeri Sunan Kalijaga Yogyakarta \\ novanhariansyah@gmail.com
}

\begin{abstract}
Segmenting or often known as market segmentation is the act of classifying the market into groups with various categories. Sixty per cents $(60 \%)$ of business failures are caused by failing to define the target market, their market potential, and failing to decide the right marketing concepts. Entrepreneurs tend to do more expansion in areas that they don't understand just because they are opportunists, making the most of people's fears and hesitancies. Marketing communication can be so powerful if it is combined with effective and efficient communication. For example, a communication on how to attract consumers or audiences to become aware, familiarized and interested in buying a product or service through communication channels. The current study is literatures study which analyses and thoroughly studies literatures to find data. In Islamic ethics, segmentation techniques in marketing communications are not justified using sexual appeal, emotional appeal, fear appeal, false testimony or pseudo-marketing research, or contribute to stupidity of mind and encourage overbuy. In the Islamic framework, these methods are unethical because they are used purely to exploit the basic instincts of consumers around the world with the aim of gaining profit and bigger market preys. In addition, Islamic ethics strictly prohibits stereotypes of women in advertising, and excessive use of "fantasy" either in product forms, services or other added value. Apart from innovation, Islamic marketing communication is also obliged to pay attention to efficiency. In order for marketing communications to be effective, we don't act on a whim. We can carry out marketing efficiency with high foresight to target markets that match the products and services we have.
\end{abstract}

Keywords: market segmentation, Islamic marketing communication.

\section{Abstrak}

Segmenting atau yang sering dikenal dengan segmentasi pasar merupakan tindakan mengklasifikasikan pasar ke dalam kelompok-kelompok dengan berbagai kategori. $60 \%$ kegagalan bisnis disebabkan karena gagalnya mendefinisikan pasar yang dituju, bagaimana potensi mereka, apa yang sebenarnya ada di kepala mereka. Pengusaha lebih banyak melakukan ekspansi pada bidang-bidang yang tidak ia pahami, kebanyakan ada aspek "aji mumpung". Mumpung banyak orang gengsi. Komunikasi. Pemasaran bisa akan begitu powerful jika dipadukan dengan komunikasi yang efektifdan efisien. Bagaimana menarik konsumen atau khalayak menjadi sadar, kenal dan mau membeli suatu produk atau jasa melalui saluran komunikasi. Pendekatan penelitian ini Metode penelitian yang digunakan merupakan metode penelitian studi 
pustaka yang merupakan telaah dari sebuah literatur. Dalam etika Islam, teknik segmentasi dalam komunikasi pemasaran tidak dibenarkan menggunakan daya tarik seksual, daya tarik emosional, daya tarik rasa takut, kesaksian palsu dan daya tarik penelitian semu, atau berkontribusi terhadap kebodohan pikiran atau mendorong pemborosan. Dalam kerangka Islam, metode ini tidak etis karena mereka digunakan murni untuk mengeksploitasi naluri dasar konsumen di seluruh dunia dengan tujuan untuk memperoleh keuntungan dan pangsa pasar yang lebih besar. Selain itu, etika Islam secara tegas melarang stereotip (stereotype) perempuan dalam iklan, dan penggunaan "fantasi" yang berlebihan. Misalnya. baik dalam bentuk produk. pelayanan,maupun nilai tambah lainnya. Selain inovasi. Komunikasi pemasaran islam juga wajib memperhatikan efisiensi. Supaya komunikasi pemasaran efektif, kita tidak terlalu sering mengatakan barangkali atau ya coba-coba. Kita dapat melakukan efisiensi pemasaran dengan kejelian yang tinggi untuk membidik pasar yang cocok dengan produk dan layanan yang dimiliki.

Kata Kunci: segmentasi pasar, Komunikasi pemasaran Islam.

\section{Pendahuluan}

Segmenting atau yang sering dikenal dengan segmentasi pasar merupakan tindakan mengklasifikasikan pasar ke dalam kelompok-kelompok dengan berbagai kategori. Sehingga kondisi tersebut memungkinkan kebutuhan produk yang berbeda atau kombinasi pemasaran yang terpisah sedangkan komunikasi pemasaran Islam dapat dikatakan sebagai konsumen. Komunikasi pemasaran dapat memberitahu atau memperlihatkan kepada konsumen tentang bagaimana dan mengapa produk itu digunakan, oleh orang macam apa, serta dimana dan kapan. Konsumen dapat mempelajari tentang produk apa, siapa yang memproduksi, mereknya apa, cocok dikonsumsi oleh siapa, apa keunggulan nya, dapat diperoleh di mana, dan bagaimana caranya memperoleh produk itu. 60\% kegagalan bisnis disebabkan karena gagalnya mendefinisikan pasar yang dituju, bagaimana potensi mereka, apa yang sebenarnya ada di kepala mereka. Pengusaha lebih banyak melakukan ekspansi pada bidang-bidang yang tidak ia pahami, kebanyakan ada aspek "aji mumpung". Mumpung banyak orang gengsi. Mumpung banyak orang kaya baru Mumpung banyak orang berspekulasi. Mumpung banyak peraturan pemerintah belum menyentuh bidang bidang tersebut. Mumpung ada hubungan baik dengan bank yang kelebihan likuiditas Sehingga para pengusaha telah terjebak kedalam sebuah kerumunan yang berkilauan tanpa memahami benar siapa konsumen yang dia bidik. ${ }^{1}$

Dengan demikian komunikasi pemasaran memiliki peran yang sangat penting bagi perusahaan untuk mengkomunikasikan produk yang dipasarkan kepada pasar sasaran secara lebih luas, bahkan dapat berkontribusi terhadap ekuitas merek dengan menanamkan merek dalam ingatan dan menciptakan citra (image) merek,

1 Hery CFRM S. E. , M. Si , CRP , RSA, Manajemen Pemasaran (Jakarta: Gramedia widiasarana indonesia, 2019), 65. 
serta mendorong penjualan, dan memperluas pasar. Kontribusi komunikasi pemasaran dalam membentuk ekuitas merek melalui bauran komunikasi komunikasi (marketing communication mix) dan kerangka dasar komunikasi umum (iklan, promosi peninjiauan, acara dan pengelaman, hubungan masyarakat dan publisitas, pemasaran langsung \& pemasaran intekaktif, dari mulut ke mulut, dan penjualan personal) akan memben tuk pemahaman konsumen terhadap: Kesadaran merek; citra merek; respon merek; dan hubungan merek.

Komunikasi. Pemasaran bisa akan begitu powerful jika dipadukan dengan komunikasi yang efektifdan efisien. Bagaimana menarik konsumen atau khalayak menjadi sadar, kenal dan mau membeli suatu produk atau jasa melalui saluran komunikasi adalah bukan sesuatu yang mudah. Komunikasi adalah sebuah usaha untuk menyampaikan pesan positif atau negatif dengan maksud tertentu yang dilakukan oleh seseorang kepada orang lain melalui media yang digunakan. Definisi singkat ini mungkin dapat menggambarkan dengan lebih jelas mengenai apa itu komunikasi. Sementara itu, pemasaran adalah segala usaha yang dilakukan dalam menyediakan barang untuk pasar, mulai dari merumuskan produk hingga mempromosikan produk tersebut ke masyarakat. Dua hal ini walaupun berbeda, akan tetapi sangat berkaitan. ${ }^{2}$

\section{Metode Penelitian}

Pendekatan penelitian ini Metode penelitian yang digunakan merupakan metode penelitian studi pustaka yang merupakan telaah dari sebuah literatur. Teknik pengumpulan data dengan mengadakan studi penelahaan terhadap buku-buku literatur-literatur, catatan-catatan, dan laporan-laporan yang ada hubungannya dengan masalah pembuktian secara informal dalam pembelajaran segmentasi pasar dalam komunikasi pemasaran islam. ${ }^{3}$

Teknik pengumpulan data pada penelitian ini dengan observasi dan dokumentasi. Dalam penelitian ini bertujuan membahas metode penelitian kualitatif studi pustaka dan studi lapangan, dengan Kesimpulan penelitian ini ialah pengguna metode penelitian jenis kualitatif studi lapangan dipastikan terlebih dahulu melaksanakan studi pustaka. ${ }^{4}$

\section{Definisi Istilah}

\section{Pengertian Segmentasi Pasar}

${ }^{2}$ Dr M. Anang Firmansyah S.E.,M.M, KOMUNIKASI PEMASARAN (Penerbit Qiara Media, 2020), 3.

${ }^{3}$ Tarjo, Metode Penelitian Sistem 3x Baca (Deepublish, 2019), 29.

4 "Bukti Informal Dalam Pembelajaran Matematika | Suandito | Al-Jabar: Jurnal Pendidikan Matematika," 13, diakses 17 Juli 2021, http://ejournal.radenintan.ac.id/ index.php/aljabar/article/view/1160. 
Kegiatan segementasi adalah upaya untuk mempunyai batasan. Segmen pasar yang pada dasarnya terdiri atas segmentasi geografis, demografis, psikografis, segmentasi perilaku, dan segmentasi manfaat. Sebagai contoh segmentasi geografis, yaitu membagi pasar menjadio unit-unit geografis berbeda seperti wilayah, Negara, kota, provinsi, kepulauan, dan berdasarkan musim. Pada masa Rasulullah SAW. terdapat pasar terkenal yang terletak di sebelah utara kota Makkah yang meliputi Busra, Dumarul Jandal, dan Nazar. Selain itu juga padaa bagian selatan kota Makkah yang meliputi Mina, Majinna, Ukaz, San'a, Aden, Shihr, Rabiyah, Sohar, dan Doba. Serta di sebelah timur kota Makkah yang meliputi Musyaqqar, Sofa, dan Hijar. $^{5}$

Dalam jurnal berjudul Market Segmentation, Targeting, dan Brand Positioning dari Winston Premier Surabaya) tentang segmentasi pasar, yaitu membagi sebuah pasar menjadi kelompok-kelompok pembeli dengan keinginan, karakteristik, atau perilaku yang berbeda-beda.), bahwa segmentasi pasar adalah proses membagi keseluruhan pasar untuk produk tertentu atau kategori produk tertentu kedalam segmen yang relatif homogen atau kedalam kelompok

Segmentasi pasar juga dapat dikelompokkan menjadi bukan pemakai, bekas pemakai, pemakai potensial, pemakai pertama kali, dan pemakai tetap. Segmentasi pasar merupakan unsur pertama dalam strategi pemasaran. Segmentasi pasar juga termasuk seni mengidentifikasi dan memanfaatkan peluang yang muncul dalam pasar. ${ }^{6}$

\section{Komunikasi Pemasaran Islam}

Efektif dan efisien pasar sasaran (target market) tidak tahu bahwa produk yang dinginkan dan diminta konsumen beredar di pasar. komunikasi pemasaran adalah sarana dimana perusahaan berusaha menginformasikan, membijuk, dan mengingatkan konsumen secara langsung maupun tidak langsung, tentang produk dan merek yang dijual. Intinya komunikasi pemasaran mempresentasikan suara perusahaan dan mereknya serta merupakan sarana dimana perusahaan dapat membuat dialog dan membangun hubungan dengan konsumen. ${ }^{7}$

\section{Manajemen Syariah}

Manajemen dalam bahasa Arab disebut dengan idarah. Idarah diambil dari perkataan adarta syyai'an atau perkataan 'adarta biha juga dapat didasarkan pada kata ad-dauran. Pengamat bahasa menilai pengambilan kata yang kedua - yaitu:

\footnotetext{
5 Veithzal Rivai Zainal, DKK, "Islamic Marketing Manajemen (Mengembangkan Bisnis dan Hijrah ke Pemasaran Islami Mengikuti Praktik Rasulullah SAW)", (Jakarta: Bumi Aksara, 2018),378-379.

${ }^{6}$ Veithzal Rivai Zainal, DKK, "Islamic Marketing Manajemen (Mengembangkan Bisnis dan Hijrah ke Pemasaran Islami Mengikuti Praktik Rasulullah SAW)", (Jakarta: Bumi Aksara, 2018),378-379.

7 Dr Redi Panuju M.Si, Komunikasi Pemasaran: Pemasaran sebagai Gejala Komunikasi Komunikasi sebagai Strategi Pemasaran (Prenada Media, 2019), 2.
}

130 | Novan Hariyansah 
'adarta ini itu lebih tepat. Karena sepadan dengan kata tadbir Tadbir adalah bentuk masdar dari kata kerja dabbara, yudabbiru, tadbiran. Tadbir berarti penertiban, pengaturan, pengurusan, perencanaan dan persiapan. Secara istilah, sebagian pengamat mengartikannya sebagai alat untuk merealisasikan tujuan umum. Karena pada dasarnya terbangunnya konsep manajemen disandarkan kepada ketiga dasar pemikiran tersebut (pencapaian tujuan, pengambilan keputusan dan pelaksanaan manajemen). Secara umum manajemen itu mempunyai tiga tugas pokok yaitu mempersiapkan rencana atau strategi umum bagi perusahaan, lalu melaksanakan rencana tersebut yang terakhir mengadakan evaluasi, menganalisa dan mengawasi rencana tersebut dalam operasinya.

Marketing syariah diartikan sebagai suatu disiplin unit bisnis strategis yang diarahkan kepada suatu proses dimana terdapat perubahan nilai serta penawaran dari satu penggagas kepada bagian yang lain dalam keseluruhannya sesuai dengan prinsip-prinsip kegiatan muamalah dalam Islam.

Hukum pemasaran (wakalah) dalam landasan ijma adalah sunnah, dikarenakan terdapat nilai-nilai yang mengandung unsur-unsur yang teramat mulia (ta'awun)yang didasarkan atas kebaikan dan taqwa. Didalam landasan fiqih segala sesuatu yang berkaitan dengan muamalah dapat dilakukan selama tidak ada suatu dalil pun yang mengharamkannya. Rukun wakalah

terdiri dari 3 (tiga) rukun yang merupakan komponen persyaratan dalam melakukan jual-beli, yaitu: terdapat penjual dan pembeli, terdapat barang/ produk/ jasa serta terdapat ijab qabul. ${ }^{8}$

\section{Pemasaran Syariah}

Pemasaran adalah salah satu kegiatan dalam perekonomian yang membantu dalam menciptakan nilai ekonomi. Nilai ekonomi itu sendiri menentukan harga barang dan jasa. Faktor penting dalam menciptakan nilai tersebut adalah produksi, pemasaran, konsumsi, dan mengomersialisasikan relasi dengan konsumen untuk jangka panjang. Pemasaran menjadi penghubung antara kegiatan produksi dan konsumsi. Definisi pemasaran ini berdasar pada konsep inti yang meliputi kebutuhan (needs), keinginan (wants), dan permintaan (demands).

Pemasaran syariah atau marketing syariah adalah sebuah disiplin bisnis strategis yang mengarahkan proses penciptaan, penawaran, dan perubahan value dari suatu inisiator kepada stakeholders, yang dalam keseluruhan prosesnya sesuai dengan akad dan prinsip-prinsip muamalah (bisnis) dalam Islam. Artinya bahwa dalam marketing syariah, seluruh proses baik proses penciptaan, proses penawaran, maupun proses perubahan nilai (value) tidak boleh ada hal-hal yang bertentangan dengan akad dan prinsip-prinsip muamalah yang islami. Sepanjang hal tersebut dapat dijamin, dan penyimpangan prinsip - prinip muamalah islami tidak terjadi

${ }^{8}$ Ahmad Miftah, "Mengenal Marketing dan Marketers Syariah," ISLAMICONOMIC: Jurnal Ekonomi Islam 6, no. 2 (15 Agustus 2015): 16, https://doi.org/10.32678/ijei.v6i2.56. 
dalam suatu interaksi atau dalam proses suatu bisnis, maka bentuk transaksi apa pun dalam pemasaran dapat dibolehkan. ${ }^{9}$

\section{Hasil Dan Pembahasan \\ Manfaat Segmen Pasar}

Perusahaan melakukan segmentasi pasar bertujuan untuk meningkatkan efektivitasstrategi pemasaran yang telah disusun menjadi lebih terarah, serta dapat menggunakan berbagai sumber daya perusahaan secara efektif dan efisien. Berikut adalah manfaat segmentasi pasar yang didapat oleh perusahaan, yaitu:

1. Perusahaan dapat menyediakan keinginan dan kebutuhan pelanggan dengan lebih baik dan sesuai dengan pola konsumen yang berbeda dengan menggunakan insentif dan promosi yang berbeda pula.

2. Dengan segmentasi, perusahaan dapat mengetahui potensi pasar yang berbeda disetiap sekmen sehingga dapat melakukan pemasaran dengan tepat untuk mendapat pendapatan yang lebih baik.

3. Perusahaan dapat meningkatkan peluang untuk tumbuh. dengan segmentasi pasar, perusahaan dapat menciptakan niche product yang menarik konsumen lain untuk mencoba. ${ }^{4}$

\section{Tahapan Segmentasi}

Untuk memenangkan persaingan pasar, perusahaan harus mengetahui bahwa tingkat persaingan bisnis memiliki keberagaman sifat. Penting bagi perusahaan untuk mengelompokkan dan memilih industry menjadi beberapa bagian dan menganalisis struktur karakteristik dari setiap bagian, kemudian menentukan daya tarik setiap segmen yang ada. Ada beberapa tahapan untuk melakukan segmentasi pasar, yaitu:

1. Mengidentifikasi variabel dan kategori kunci dalam segmentasi

2. Menyusun matriks segmentasi

3. Menganalisis daya tarik setiap segmentasi

4. Mengidentifikasi faktor kunci kesuksesan untuk tiap-tiap segmen

5. Menganalisis daya tarik ruang lingkup segmen yang sempit dan luas. ${ }^{10}$

\section{Kriteria Segmen Yang Efektif}

Tidak semua skema dapat bermanfaat. Ada beberapa kriteria yang harus diketahui oleh perusahaan supaya analisis segmentasi pasar menjadi efektif, yaitu:

1. Segmen pasar harus dapat dijangkau (accessable)

2. Segmen pasar harus dapat diukur (measureable)

\footnotetext{
${ }^{9}$ Nurul Huda dkk., Pemasaran Syariah: Terori \& Aplikasi (Kencana, t.t.), 5.

${ }^{10}$ Veithzal Rivai Zainal, DKK, "Islamic Marketing Manajemen (Mengembangkan Bisnis dan Hijrah ke Pemasaran Islami Mengikuti Praktik Rasulullah SAW)", (Jakarta: Bumi Aksara, 2018),381-384. Veithzal Rivai Zainal, DKK, "Islamic Marketing Manajemen (Mengembangkan Bisnis dan Hijrah ke Pemasaran Islami Mengikuti Praktik Rasulullah SAW)", (Jakarta: Bumi Aksara, 2018),384-385.
}

132 | Novan Hariyansah 
3. Segmen pasar harus dapat memberikan keuntungan (profitable)

4. Segmentasi pasar harus memiliki ukuran cukup besar sehingga menguntungkan untuk dilayani.

5. segmen pasar harus dapat dijangkau dengan efektif

6. Segmen pasar secara konseptual harus dapat dibedakan dan memberikan tanggapan yang berbeda terhadap unsur dan program bauran yang berbeda.

7. Segmen pasar harus memiliki program yang efektif untuk dilaksanakan. ${ }^{6}$

\section{Penetapan Target Pasar Dalam Islam}

Setelah melakukan segmentasi pasar, perusahaan dapat menetapkan sasaran pasar yang akan dilayani ( Target Market).Perusahaan harus mengevaluasi setiap segmen untuk menentukan daya tarik dan peluang segmen tersebut yang cocok dengan kapabilitas dan sumber daya perusahaan .Dengan mengidentifikasikan bagian pasar yang dapat dilayani secara efektif, perusahaan akan berada pada posisi yang lebih baik dengan melayain konsumen tertentu dari pasar tersebut. Menurut Ferrell dan Hartline (2011), ada lima strategi dasar untuk pemilihan target pasar ${ }^{11}$, yaitu:

1. Single Segment Targeting

2. Selective Targeting

3. Mass Market Targeting

4. Product Specialization

5. Market Specialization

Penetapan target pasar (targeting) adalah proses pemilihan target dan mencocokkan reaksi pasar dengan kebutuhan dasar, daya beli, dan keterbatasan yang dimiliki. Sebelum produk diluncurkan, hal yang harus dilakukan setelah segmentasi adalah pemilihan target. Karena produk bisnis atau perusahaan tidak bisa memasuki semua segmen. Ketelitian dalam memilih target pasar dapat memudahkan produk baru akan diterima masyarakat. ${ }^{8}$

Targeting dalam masa Rasulullah SAW menggambarkan sebuah perencanaan yang sempurna. Seperti pemilihan kota Madinah sebagai target dakwah Rasulullah merupakan pemilihan yang tepat sehingga agama islam dapat berkembang pesat di sana. Selain untuk sarana dakwah, Madinah juga dijadikan sarana target perdagangan. Bukan tanpa alasan, Madinah termasuk daerah yang memiliki pertahanan alam yang sangat baik. Selain itu, Jazira Arab merupakan tempat yang sangat kondusif untuk melakukan berbagai kegiatan termasuk kegiatan perdagangan. Penduduk Madina juga dikenal sebagai penduduk yang kuat dalam

11 Debby Tania dan Diah Dharmayanti, "Market Segmentation, Targeting, dan Brand Positioning dari Winston Premier Surabaya", jurnal vol. 3 No. 1, Universitas Kristen Petra, Surabaya, 2014, 2. 8 Veithzal Rivai Zainal, DKK, "Islamic Marketing Manajemen (Mengembangkan Bisnis dan Hijrah ke Pemasaran Islami Mengikuti Praktik Rasulullah SAW)", (Jakarta: Bumi Aksara, 2018),398-399. 
mempertahankan kehormatan dan harga dirinya. Mereka juga dikena sebagai masyarakat yang gigih, pendiam, dan pantang menyerah.

Rasulullah berhasil melakukan segmentasi secara keseluruhan dan tidak hanya menargetkan salah satu segmen pasar. Rasulullah berhasil melakukan target mulai dari raja hingga budak. Karena itu kita tahu bahwa Rasulullah berhasil menciptakan one brand for all dengan positioning yang berbeda untuk segala bagian segmen pasar. Setiap individu dapat dijadikan segmentasi pasar. Rasulullah dikenal dan disegani di kalangan pengusaha. Selain karena ketelitian Rasulullah, juga karena sifat beliau yang amanah dalam menjalankan bisnisnya. Semua ucapan dan perbuatannya diteladani serta dapat dijadikan contoh oleh setiap orang. Dalam hal ini bisa dikatakan Rasulullah tidak hanya melalakukan targeting dalam hal bisnis, namun juga dalam aspek personal.

Dengan demikian, langkah ini dapat menghasilkan costumer lifetime value yaitu nilai yang bisa didapatkan oleh perusahaan dalam jangka waktu tertebtu selama pelanggan menggunakan produk perusahaan. Costumer lifetime value dapat berujung pada long term relationship atau hubungan jangka panjang antara perusahaan dan pelanggan. ${ }^{12}$

\section{Konsep Pemasaran}

Konsep pemasaran (marketing concept) beranggapan bahwa kunci untuk mencapai tujuan organisasi terdiri dari penentuan kebutuhan, keinginan pasar sasaran, serta memberikan kepuasan kepada konsumen yang diharapkan secara lebih efektif dan efisien dibandingkan para pesaing. Tjiptono dan Chandra menjelaskan lebih perinci, nilai pelanggan (Customer value) adalah rasio antara apa yang diperoleh pelanggan dan apa yang ia berikan. Iadi, rumusan nilai pelanggan adalah:

NILAI PELANGGAN $=[$ manfaat - biaya $]=[$ manfaat fungsional + manfaat emosional] - [biaya moneter + biaya waktu + biaya energi + biaya psikis]

Empat pilar dalam konsep pemasaran terdiri dari pasar sasaran (target market), kebutuhan konsumen, pemasaran yang terintegrasi (intergrated marketing), dan profitabilitas. ${ }^{13}$

\section{Tujuan Pemasaran}

Tujuan akhir konsep pemasaran ini adalah membantu tercapainya tujuan dari

\footnotetext{
${ }^{12}$ Veithzal Rivai Zainal, DKK, "Islamic Marketing Manajemen (Mengembangkan Bisnis dan Hijrah ke Pemasaran Islami Mengikuti Praktik Rasulullah SAW)", (Jakarta: Bumi Aksara, 2018),399.

${ }^{13}$ Huda dkk., Pemasaran Syariah, 6.
} 
organisasi. Tujuan utama dari organisasi bisnis adalah laba, sedangkan tujuan organisasi nirlaba dan organisasi sosial adalah memperoleh dana untuk aktivitas sosial ataupun aktivitas pelayanan publik.

Tujuan pemasaran menurut Drucker adalah untuk mengetahui dan memahami pelanggan dengan baik sehingga produk atau jasa sesuai dan dengan sendirinya terjadilah penjualan. Idealnya, pemasaran harus menghasilkan pelanggan yang siap untuk membeli. Caranya adalah dengan membuat produk atau jasa tersedia. Untuk memahami fungsi pemasaran, kita perlu memahami serangkaian konsep inti dalam pemasaran.

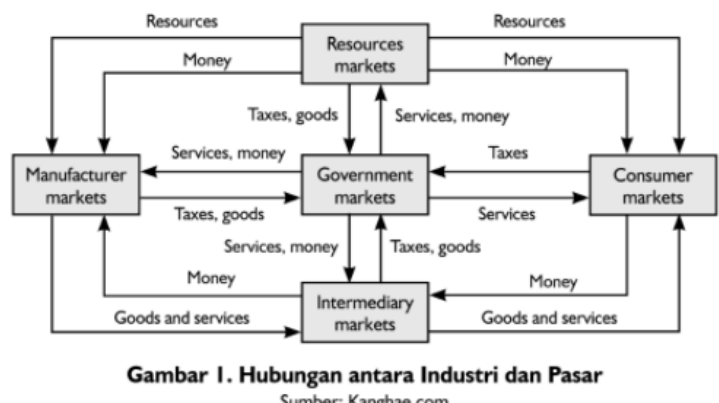

\section{Peran Komunikasi Pemasaran}

Dalam operasional perusahaan komunikasi pemasaran memiliki peran yang sangat penting, seperti yang disampaikan Philip Kotler \&Kevin Lane Killer dalam sebuah organisasi atau perusahaan komunikasi pemasaran memiliki peranan memberikan informasi, membujuk,mengingatkan konsumen secara langsung maupun tidak langsung tentang produk dan merek yang dijual. Komunikasi pemasaran melaksanakan banyak fungsi kepada konsumen atau pasar sasaran terutama memberitahu dan memper lihatkan sputar bagaimana dan mengapa produk itu digunakan, siapa pasar sasarannya, dimana dan kapan produk itu dapat diperoleh. Lingkungan komunikasi pemasaran sesuai dengan perkem bangan teknologi proses komunikasi juga mengalami perubahan, seperti halnya akhir-akhir ini maraknya perkembangan internet. Tentunya ini juga akan berpengaruh terhadap konsumen dalam memperoleh informasi suatu produk.

Komunikasi pemasaran mampu membentuk ekuitas merek dan penjualan produk. Memang dikatakan oleh Kotler \& Keller, dalam perkembangan lingkungan komunikasi pemasaran yang perubahannya sangat cepat komunikasi pemasaran melalui iklan bukanlah satu-satunya atau bahkan yang paling penting dalam membentuk ekuitas merek dan mendorong penjualan, namun dengan melalui buram komunikasi pemasaran yang dilaksanakan secara terintegrasi dapat meningkatkan ekuitas dan mendoronga penjualan, bahkan dengan meluasnya komunikasi ini dapat menjangkau pasar yang lebih luas. Bauran komunikasi pemasaran (marketing 
communication mix) agar dapat mendorong efektifitas dan efisiensi komunikasi pemasaran terdiri dari delapan model komunikasi utama. ${ }^{14}$

\section{Komunikasi Pemasaran (Prinsip Islam)}

Dewasa ini sering dijumpai cara pemasaran yang tidak etis, curang dan tidak profesional, halini dapat mengganggu orang lain. Oleh karenanya komunikasi pemasaran kategori konvensional perlu dikaji ulang dan dilihat dari sudut pandang nilai dan aspek Islam. Karena itu peneliti berusaha untuk melakukan re-definisi kata demi kata mengenai "komunikasi" dan "pemasaran" berbasis "prinsip/syariah/ aspek/nilai" Islam yang merujuk pada beberapa pendapat/kutipan dan referensi para ahli. Kertajaya (2005) berpendapat bahwa "kegiatan marketing atau pemasaran seharusnya dikembalikan pada karakteristik yang sebenarnya, yakni relegius, beretika, realistis dan menjunjung tinggi nilai-nilai kemanusiaan. Inilah yang dinamakan marketing syariah, dan inilah konsep terbaik marketing untuk hari ini dan masa depan". Pemasaran (marketing) prinsip Islam adalah sebuah disiplin bisnis yang seluruh proses, baik proses penciptaan, proses penawaran, maupun proses perubahan nilai (value), tidak boleh ada hal-hal yang bertentangan dengan akad dan prinsip-prinsip muamalah yang Islami.

Pemasaran syariah sendiri menurut definisi adalah suatu disiplin bisnis strategis yang sesuai dengan nilai dan prinsip syari'ah).Pemasaran syariah dijalankan didasari oleh prinsip dan konsep keislaman. Jadi nilai inti pemasaran syariah adalah integritas, dan transparansi sehingga marketer tidak boleh bohong dan orang membeli karena butuh dan sesuai dengan keinginan dan kebutuhan, bukan karena daya tarik harga (mis: diskon), daya tarik emosional (mis: testimoni tokoh/selebritas/seksualitas) atau imingiming janji hadiah dan penelitian semu belaka. Menurut Kotler, Kertajaya, Huan dan Liu, ada beberapa dimensi yang dapat dijadikan pertimbangan sebagai pembeda antara pemasaran konvesional dan pemasaran prinsip Islam, diantaranya adalah: a. Prinsip Dasar. Pertama, Prinsip Iman dan Keyakinan atau transendental. Ilmu komunikasi dan pemasaran bila dikaitkan dengan aspek Islami tentu mutlak harus berprinsip dan kaidah Islam. Kedua, Prinsip Operasional. Hukum Islam (Syariah) adalah kerangka kerja frame of work yang meliputi:

a. Perkataan dan amal (perbuatan) sertainteraksinya dengan seluruh elemen pendukungnya (alat, media).

b. Sistem dan Operasional Perusahaan (Komunikasi Pemasaran Syariah). Aktifitas ini harus berprinsip dasar Islam. Contohnya pada internal perusahaan, hubungan dengan para karyawan, kultur dan tata kelola, etika pergaulan antara laki-laki dan perempuan, sampai etika berpakaian dan tingkah laku. Kesemuanya

${ }^{14}$ M.Si, Komunikasi Pemasaran, 6.

136 | Novan Hariyansah 
tersebut haruslah syar'i (menurut aturan dan hukum Islam).

c. Segmentasi. Selama tidak bertentangan dengan "Prinsip Dasar", tidak ada batasan segmentasi. Siapapun tanpa dibatasi oleh apapun bisa menjadi segmen pasar.

d. Keuntungan (Profit). Tidak menghalalkan segala cara, sehingga keuntungan yang diperoleh (dalam paradigma Islam) menjadi berkah. Sebuah konsep yang tidak dimiliki oleh sistem konvensional non syariah (contohnya: kapitalis, sosialis).

e. Cakupan kerja. Aktivitas komunikasi pemasaran dapat dilakukan selama: (1) Tidak bertentangan dengan keimanan dan aqidah; (2) Tidak merencanakan, mengkomunikasikan, dan merancang produk yang diharamkan, namun dibuat/dibungkus dengan balutan pencitraan atau hasil penelitian sehingga seolah-olah dapat dihalalkan; (3) Tidak menggunakan ikon atau visualisasi yang dilarang syariah; (4) Tidak menggunakan foto atau gambar makhluk hidup bernyawa, kecuali kartun atau gambar 1 dimensi yang tidak dapat diraba dan tidak sempurna yang tidak mungkin makhluk itu dapat hidup; (5) Tidak ada kebohongan dan kepalsuan.

f. Pola kemitraan/ kerjasama yang syar'i.Hubungan ini adalah amanah yang wajib dipenuhi sesuai kesepakatan kedua pihak. Penyimpangan terhadap amanah dapat merugikan kedua pihak dan berdosa. ${ }^{15}$

\section{Kesimpulan}

Dalam etika Islam, teknik segmentasi dalam komunikasi pemasaran tidak dibenarkan menggunakan daya tarik seksual, daya tarik emosional, daya tarik rasa takut, kesaksian palsu dan daya tarik penelitian semu, atau berkontribusi terhadap kebodohan pikiran atau mendorong pemborosan. Dalam kerangka Islam, metode ini tidak etis karena mereka digunakan murni untuk mengeksploitasi naluri dasar konsumen di seluruh dunia dengan tujuan untuk memperoleh keuntungan dan pangsa pasar yang lebih besar. Selain itu, etika Islam secara tegas melarang stereotip (stereotype) perempuan dalam iklan, dan penggunaan "fantasi" yang berlebihan. Penggunaan bahasa sugestif (suggestive) dan perilaku, serta penggunaan perempuan sebagai obyek untuk memikat dan menarik pelanggan juga tidak diperbolehkan.

Bisnis yang membawa nama syariah harus berorientasi empat hal, yaitu inovasi, efisiensi, servis, dan tanggung jawab. Inovasi merupakan roh pemasaran karena setiap pemain pasar terbuka harus memiliki keunggulan yang membedakan dengan pemain yang lain. Misalnya. baik dalam bentuk produk. pelayanan,maupun

${ }^{15}$ Eko Putra Boediman dan Armaini Lubis, "PRINSIP-PINSIP ISLAM DALAM AKTIFITAS KOMUNIKASI PEMASARAN DI AGEN PERJALANAN," Avant Garde 4, no. 1 (23 Juli 2016): 4, https://doi.org/10.36080/avg.v4i1.212. 
nilai tambah lainnya. Selain inovasi. Komunikasi pemasaran islam juga wajib memperhatikan efisiensi. Supaya komunikasi pemasaran efektif, kita tidak terlalu sering mengatakan barangkali atau ya coba-coba. Kita dapat melakukan efisiensi pemasaran dengan kejelian yang tinggi untuk membidik pasar yang cocok dengan produk dan layanan yang dimiliki. Dengan demikian, produsen mampu menyuguhkan produk dan layanan untuk nasabah yang benar-benar membutuhkan sesuai dengan preferensi, daya beli, umur. situasi. dan jenis kelamin. Prospek bisnis syariah sudah menjadi permintaan pasar Indonesia. Oleh karena itu, perlu disiapkan teori-teori bisnis untuk dapat menjawab peluang yang sudah di depan mata. Komunikasi Pemasaran Islam sudah menjawab akan teori bisnis Islam dan peluangnya. ${ }^{16}$

\section{Daftar Pustaka}

Boediman, Eko Putra, dan Armaini Lubis. "PRINSIP-PINSIP ISLAM DALAM AKTIFITAS KOMUNIKASI PEMASARAN DI AGEN PERJALANAN." Avant Garde 4, no. 1 (23 Juli 2016). https://doi.org/10.36080/avg.v4i1.212.

"Bukti Informal Dalam Pembelajaran Matematika | Suandito | Al-Jabar: Jurnal Pendidikan Matematika." Diakses 17 Juli 2021. http://ejournal.radenintan.ac.id/index.php/al-jabar/article/view/1160.

CFRM, Hery, S. E. , M. Si , CRP , RSA. Manajemen Pemasaran. Jakarta: Gramedia widiasarana indonesia, 2019.

Huda, Nurul, Khamim Hudori, Rizal Fahlevi, Badrussa'diyah, Dea Mazaya, dan Dian Sugiarti. Pemasaran Syariah: Terori \& Aplikasi. Kencana, t.t.

Miftah, Ahmad. "Mengenal Marketing dan Marketers Syariah." ISLAMICONOMIC: Jurnal Ekonomi Islam 6, no. 2 (15 Agustus 2015). https://doi.org/10.32678/ijei.v6i2.56.

M.Si, Dr Redi Panuju. Komunikasi Pemasaran: Pemasaran sebagai Gejala Komunikasi Komunikasi sebagai Strategi Pemasaran. Prenada Media, 2019.

Nasir, Munawir. Etika dan Komunikasi dalam Bisnis: Tinjauan Al-Qur'an, Filsafat dan Teoritis. CV. Social Politic Genius (SIGn), 2020.

S.E.,M.M, Dr M. Anang Firmansyah. KOMUNIKASI PEMASARAN. Penerbit Qiara Media, 2020.

Tarjo. Metode Penelitian Sistem 3x Baca. Deepublish, 2019.

${ }_{16}$ Munawir Nasir, Etika dan Komunikasi dalam Bisnis: Tinjauan Al-Qur'an, Filsafat dan Teoritis (CV. Social Politic Genius (SIGn), 2020), 150.

138 | Novan Hariyansah 